\title{
Regenerative procedure using rotary titanium brush for surface decontamination of peri-implantitis: 3 cases with a 2-year follow-up
}

\author{
Min-Woo Baek', Jeoung-A Yu', Seong-Ho Choi ${ }^{2}$, Dong-Woon Lee* \\ 'Department of Periodontology, Veterans Health Service Medical Center, Seoul, Republic of Korea \\ ${ }^{2}$ Department of Periodontology, Research Institute for Periodontal Regeneration, Yonsei University College of Dentistry, \\ Seoul, Republic of Korea
}

Peri-implantitis, in which inflammation caused by plaque and biofilm on the implant surface spreads to the hard tissue, can be treated by decontamination of the implant surface and reconstruction of the lost hard tissue through surgical methods. We have described the management of 3 peri-implantitis cases by decontamination of the implant surface using a round titanium brush and regenerative therapy. All cases showed clinical improvements, and no further radiographic bone loss was observed during a 2-year follow-up. This treatment method can be effective for clinical improvement and bone regeneration. However, a longer follow-up period is necessary to support these outcomes. (J Dent Rehabil Appl Sci 2021;37(4):259-67)

Key words: dental implants; peri-implantitis; bone regeneration

\section{Introduction}

Peri-implantitis refers to irreversible inflammation of the tissues surrounding a dental implant and can result in implant loss if left untreated. ${ }^{1}$ A recent systematic review reported that the prevalence of peri-implant mucositis, which is the inflammation of the soft tissue surrounding a dental implant, is $43 \%$ while that of peri-implantitis, which is the inflammation of the soft and hard tissues surrounding a dental implant, is $22 \%$. $^{2}$ Since the mid-1960s, implants have become an established treatment method for replacement of missing teeth. It is important to implement measures against implant-related complications since the incidence of these complications continues to rise. $^{3}$

\footnotetext{
*Correspondence to: Dong-Woon Lee

Chair, Department of Periodontology, Veterans Health Service Medical Center,

53 Jinhwangdo-ro 61-gil, Gangdong-gu, Seoul, 05368, Republic of Korea

Tel: +82-2-2225-1928, Fax: +82-2-2225-1659, E-mail: dongden@daum.net

Received: August 30, 2021/Last Revision: October 7, 2021/Accepted: October

18,2021
}

Peri-implantitis treatment methods are largely categorized as non-surgical or surgical method. Nonsurgical methods are essential in preparing tissues before the surgical procedure and include the use of curettes of various shapes to clean the implant surface, prescription of local or systemic antibiotics, or removal of the bacterial biofilm by laser or ultrasound. ${ }^{4}$ Non-surgical methods provide limited accessibility to the implant compared to surgical methods and do not allow simultaneous regeneration of hard and soft tissues; thus, they have limited efficacy in the management of peri-implantitis accompanied by bone loss. ${ }^{5}$ Owing to these limitations, surgical management is deemed necessary.

Surgical methods offer high implant accessibility and wide visualization during treatment of peri-im-

Copyright(C) 2021 The Korean Academy of Stomatognathic Function and Occlusion. (c) It is identical to Creative Commons Non-Commercial License. 
plantitis accompanied by tissue loss, and are classified as access flap, resective, or regenerative approaches. The choice between these options is based on the shape of the bone defect. Resective procedures are recommended for horizontal bone defects, while regenerative procedures are recommended for vertical bone defects; a combination of the two is recommended for complex bone defects. ${ }^{6}$

Studies have reported decontamination of the implant surface with hydrogen peroxide following flap elevation, Teflon curettes and abrasive sodium carbonate air powder, titanium-coated Gracey curettes or carbon fiber curettes with subsequent systemic antibiotic administration, $0.2 \%$ chlorhexidine mouthwash, and placement of a bone graft and collagen membrane over the defect. ${ }^{7,8}$ While these methods have achieved clinical improvements and their longterm effects have been assessed, evidence regarding the effectiveness of these methods is still lacking.

A rotary titanium brush (R-Brush, NeoBiotech, Seoul, Korea) with titanium bristles was developed to decontaminate and change the surface topology of an implant affected by peri-implantitis. The brush may be useful for Class Ie peri-implant defects characterized by circumferential bone loss with intact buccal and lingual bone or Class II peri-implant defects characterized by horizontal and supra-alveolar bone loss. ${ }^{10,11}$ This case report presents three cases of severe peri-implantitis treated by non-surgical methods followed by surgical therapy involving a rotary titanium brush and guided bone regeneration (GBR). The study protocol was approved by the institutional review board (BOHUN IRB No. 2021-01-042).

\section{Case Report}

\section{Case 1}

A 71-year-old man consulted us in July 2018 with a complaint of discomfort around an implant in the anterior mandible. The teeth from the left mandibular canine (i33) to the right mandibular central incisor (i41) had been restored by two internal connectiontype implants and cemented-type fixed prostheses 7 years earlier. The left mandibular central incisor (i31) had a 7-mm-deep pocket and bleeding on probing. Gingival recession had occurred on the buccal side and the keratinized gingiva was insufficient (Fig. 1A, Table 1). Periapical radiographs revealed radiolucent bone defects along the marginal bone of i31. After initial non-surgical treatment, surgical therapy was performed. After removing the prostheses, a flap was raised to expose the bone defect surrounding i31. A full-thickness mucoperiosteal flap, from the mesial to distal adjacent teeth, was raised under local anesthesia. Supra-alveolar and horizontal bone loss was observed buccal and lingual to the implant following granulation tissue removal. The patient was diagnosed with a Class II peri-implantitis defect, as described previously (Fig 1B). ${ }^{10}$ The surface of the implant was cleaned using a rotary titanium brush (R-Brush, NeoBiotech) at $8000 \mathrm{rpm}$ for $30 \mathrm{~s}$ per thread (Fig. 1C). Following $50 \mathrm{mg} / \mathrm{mL}$ tetracycline cotton pellet application for $90 \mathrm{~s}$, the implant surface was washed with saline solution. Porcine bone mineral (THE Graft, Purgo, Seoul, Korea) and a titanium-reinforced polytetrafluoroethylene membrane (PM1424, B\&Medi, Seoul, Korea) were applied to the implant surface, and a bone tack (truFIX, ACE Surgical Supply, Brockton, USA) was fixed on the buccal side of the implant. To augment the thin gingiva, subepithelial connective tissue $(15 \times 10 \mathrm{~mm})$ obtained from the palatal surface was positioned above the membrane and sutured. The tissue healed and remained intact without membrane exposure. Six months following GBR, the site of the bone defect was favorable for membrane removal surgery (Fig. 1E). The previously removed prostheses were reinstalled (Fig. 1F). Clinical and radiographic parameters, as described previously, ${ }^{10,12}$ were recorded at baseline and at the 2-year follow-up. These parameters were the bone defect shape, modified plaque index (mPI), modified sulcus bleeding index (mSBI), the mean probing depth at 6 sites around the implant (PD), and the distance from the implant shoulder to the first bone-to-implant contact (DIB). The mPI, mSBI, PD, and DIB of i31 decreased from 1.5 to $0.25,1.5$ to $0.5,7 \mathrm{~mm}$ to $3 \mathrm{~mm}$, and $5.7 \mathrm{~mm}$ to 1.3 $\mathrm{mm}$, respectively, over two years (Table 1). 

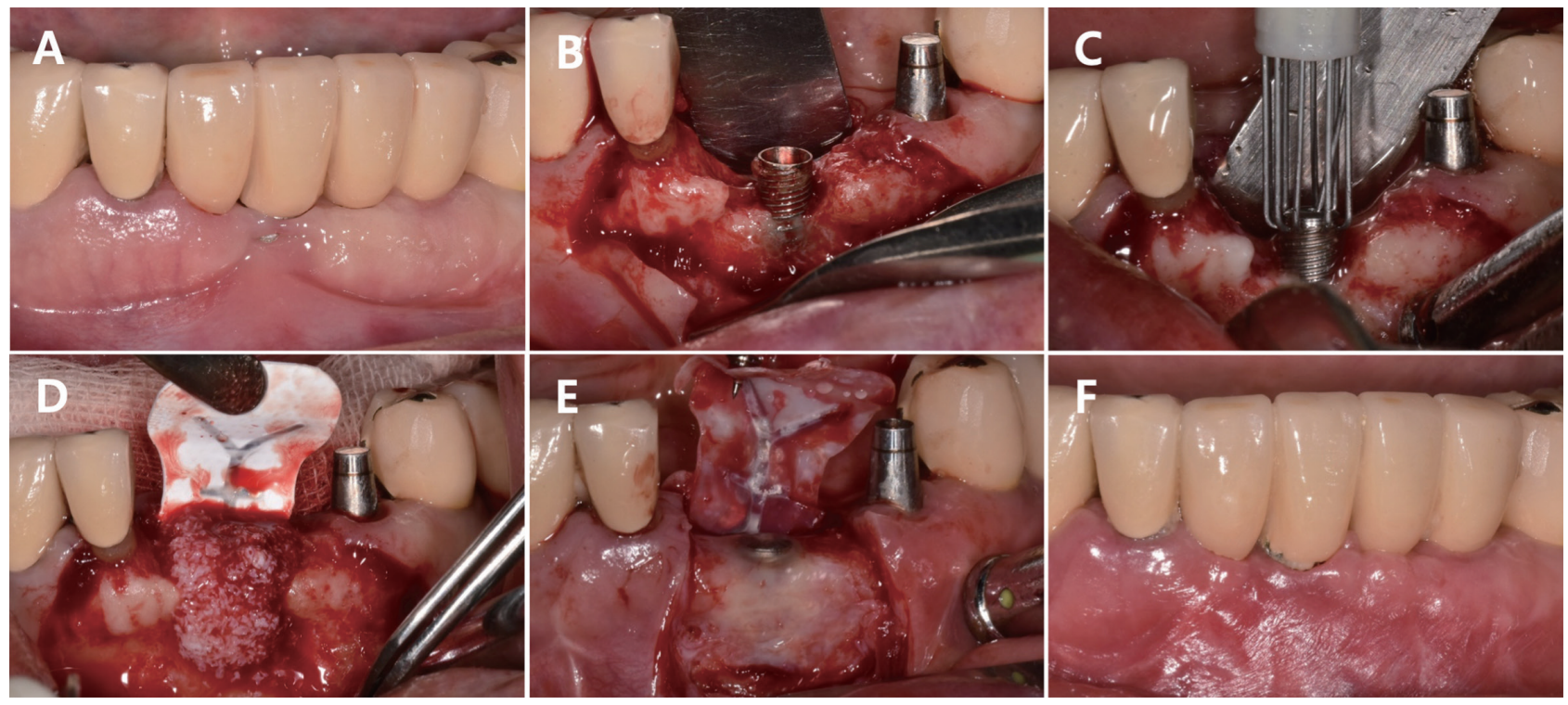

Fig. 1. Clinical photo of Case 1. (A) Preoperative photo. Note the deficient bone defect on the buccal side of implant on the lower left central incisor, (B) Flap reflection. Note the supra-alveolar defect (Class II defect type by Schwarz et al., $2010^{17}$ ), (C) Application of titanium brush for surface decontamination, (D) Non-resorbable membrane and bone graft, (E) Re-entry surgery after 6 months. (F) Two-year follow-up.

Table 1. Clinical and radiographic parameters at baseline and 2-year follow-up visit

\begin{tabular}{|c|c|c|c|c|c|}
\hline & $\begin{array}{l}\text { Modified plaque } \\
\text { index }\end{array}$ & $\begin{array}{l}\text { Modified sulcus } \\
\text { bleeding index }\end{array}$ & $\begin{array}{l}\text { Probing depth } \\
\qquad(\mathrm{mm})\end{array}$ & $\begin{array}{c}\text { Marginal bone level } \\
(\mathrm{mm})\end{array}$ & $\begin{array}{c}\text { Defect } \\
\text { classification }\end{array}$ \\
\hline $\begin{array}{l}\text { Case } 1 \text { (i31) } \\
\text { Baseline } \\
\text { Follow-visit }\end{array}$ & $\begin{array}{l}1.5 \\
0.25\end{array}$ & $\begin{array}{l}1.5 \\
0.5\end{array}$ & $\begin{array}{l}7 \\
3\end{array}$ & $\begin{array}{l}5.7 \\
1.3\end{array}$ & II \\
\hline $\begin{array}{l}\text { Case } 2 \text { (i37) } \\
\text { Baseline } \\
\text { Follow-visit }\end{array}$ & $\begin{array}{l}1.5 \\
0.5\end{array}$ & $\begin{array}{l}2 \\
0.5\end{array}$ & $\begin{array}{l}8.8 \\
3\end{array}$ & $\begin{array}{l}4.3 \\
1.7\end{array}$ & $\mathrm{Ie}$ \\
\hline $\begin{array}{l}\text { Case } 3 \text { (i13) } \\
\text { Baseline } \\
\text { Follow-visit }\end{array}$ & $\begin{array}{l}0.75 \\
0\end{array}$ & $\begin{array}{l}1 \\
0\end{array}$ & $\begin{array}{l}9.3 \\
3\end{array}$ & $\begin{array}{l}6.2 \\
2.8\end{array}$ & Ic \\
\hline $\begin{array}{l}\text { Case } 3 \text { (i14) } \\
\text { Baseline } \\
\text { Follow-visit }\end{array}$ & $\begin{array}{l}0.75 \\
0\end{array}$ & $\begin{array}{l}1 \\
0\end{array}$ & $\begin{array}{l}9.8 \\
3\end{array}$ & $\begin{array}{l}9.2 \\
3.4\end{array}$ & Ic \\
\hline
\end{tabular}

Marginal bone level, distance from the implant shoulder to the first bone-to-implant contact; II (supra-alveolar), Ie (circumferential), and Ic (intrabony) defects were classified by defect classification, as described previously. ${ }^{9}$

\section{Case 2}

A 71-year-old man consulted us in December 2019 for discomfort in relation to the implant in the left posterior mandible (i36, i37), which had been placed 9 years earlier. The left posterior mandibular teeth were restored by placing two internal-type implants and cemented-type fixed prostheses on the mandibular first and second molars. The posterior splinted implant (i37) had a 9-mm-deep pocket with suspected circumferential bone loss and exudate through the buccal gingival sulcus (Fig. 2A). Periapical radiographs showed vertical, radiolucent bone loss along the marginal bone of i37. Following nonsurgical treatment, surgical therapy comprising a mucoperiosteal flap and removal of granulation tissue was performed. Circumferential bone loss (Class Ie) was observed around the implant (Fig. 2B). Similar 

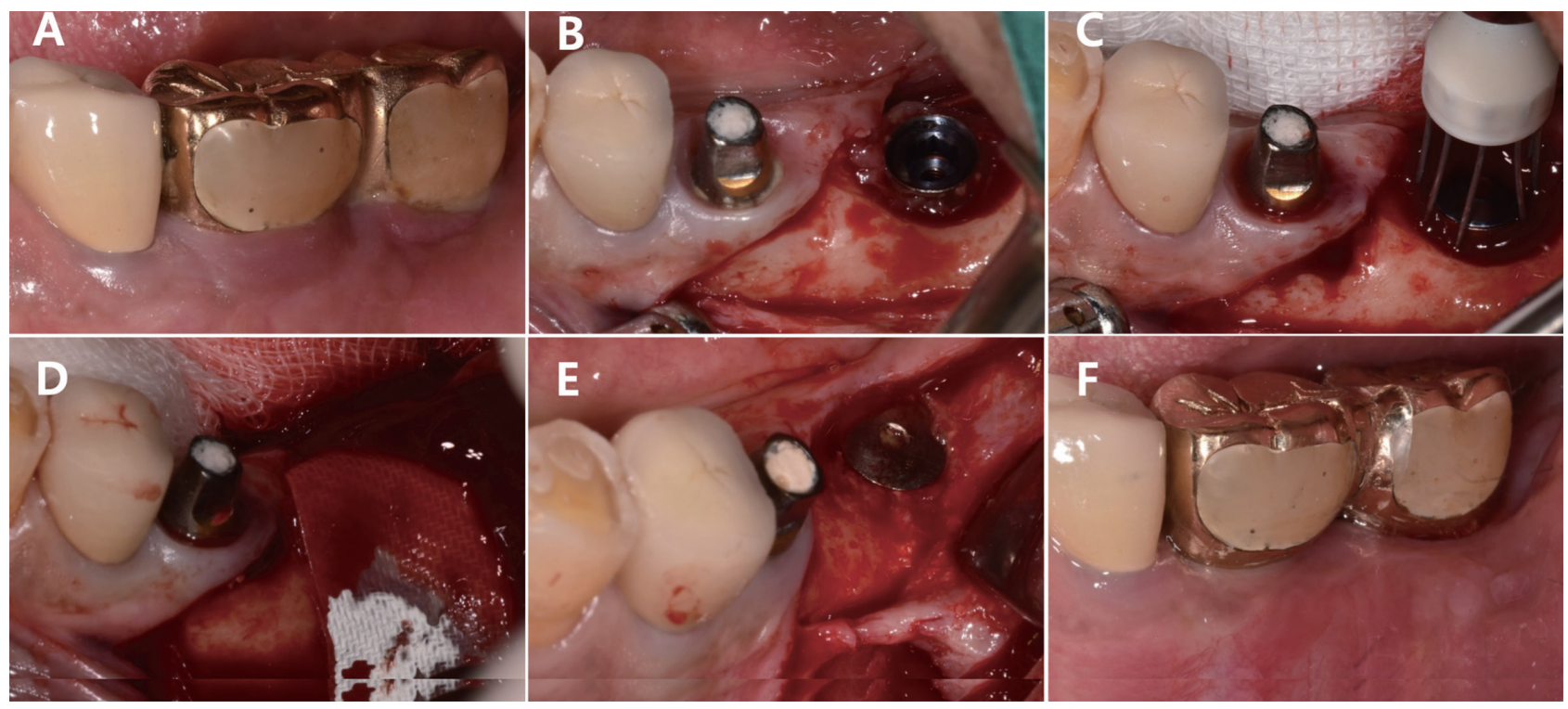

Fig. 2. Clinical photo of Case 2. (A) Preoperative photo. Note the pus discharge and gingival swelling on the lower left $2^{\text {nd }}$ molar, (B) Flap reflection. Note the circumferential defect (Class le defect type by Schwarz et al., 2010 ${ }^{17}$ ), (C) Application of titanium brush for surface decontamination, (D) Resorbable membrane and bone graft. (E) Re-entry surgery after 6 months, (F) Two-year follow-up.

to Case 1 , a rotary titanium brush was used to clean the implant surface (Fig. 2C). Tetracycline was applied, and a cover screw was placed. The implant was covered with porcine bone mineral (THE Graft, Purgo) and a resorbable membrane (Ossixplus, Datum Dental, Lod, Israel), and the flap was sutured (Fig. 2D). Healing was observed at the site of the bone defect when the flap was raised again 5 months later (Fig. 2E). Vestibule deepening was performed using a partial-thickness flap, and a healing abutment was connected and sutured. The previously removed prostheses were reinstalled with a wider embrasure for easier cleaning (Fig. 2F). Clinical and radiographic parameters were measured and recorded. The mPI, mSBI, PD, and DIB of i37 decreased from 1.5 to 0.5 , 2 to $0.5,8.8 \mathrm{~mm}$ to $3 \mathrm{~mm}$, and $4.3 \mathrm{~mm}$ to $1.7 \mathrm{~mm}$, respectively, over two years (Table 1$)$.

\section{Case 3}

A 66-year-old man visited us in November 2018 with a chief complaint of discomfort with respect to the right anterior maxillary implant. Five implants were placed in the right maxillary first premolar (i14), canine (i13), and central incisor (i11), and the left central incisor (i21) and canine (i23), followed by cemented-type fixed prostheses on all teeth from the right first premolar to the left canine. i13 and i14 had a 10-mm-deep pocket with exudate at the buccal gingival sulcus (Fig. 3A). Periapical radiographs revealed marginal bone loss surrounding 113 and i14. Following non-surgical therapy, surgical treatment comprising a mucoperiosteal flap and removal of granulation tissue was performed. Significant exposed portions (4-5 threads) were observed at both implants (Fig. 3B). The implants were cleaned with a rotary titanium brush (Fig. 3C) and treated with tetracycline cotton pellets followed by placement of porcine bone mineral (THE Graft, Purgo). Since the cover screws for the implants could no longer be acquired, cover screws from another manufacturer (Osstem, Seoul, Korea) were fixed with an acellular dermal matrix (Megaderm, L\&C Bio, Seoul, Korea) to cover the implant threads (Fig. 3D). Two months later, 2 $\mathrm{mm}$ and $1 \mathrm{~mm}$ of the crestal areas of 113 and i14, respectively, were exposed (Fig. 3E). The previously removed prostheses were reinstalled. No bleeding was observed upon probing, and the patient reported no 

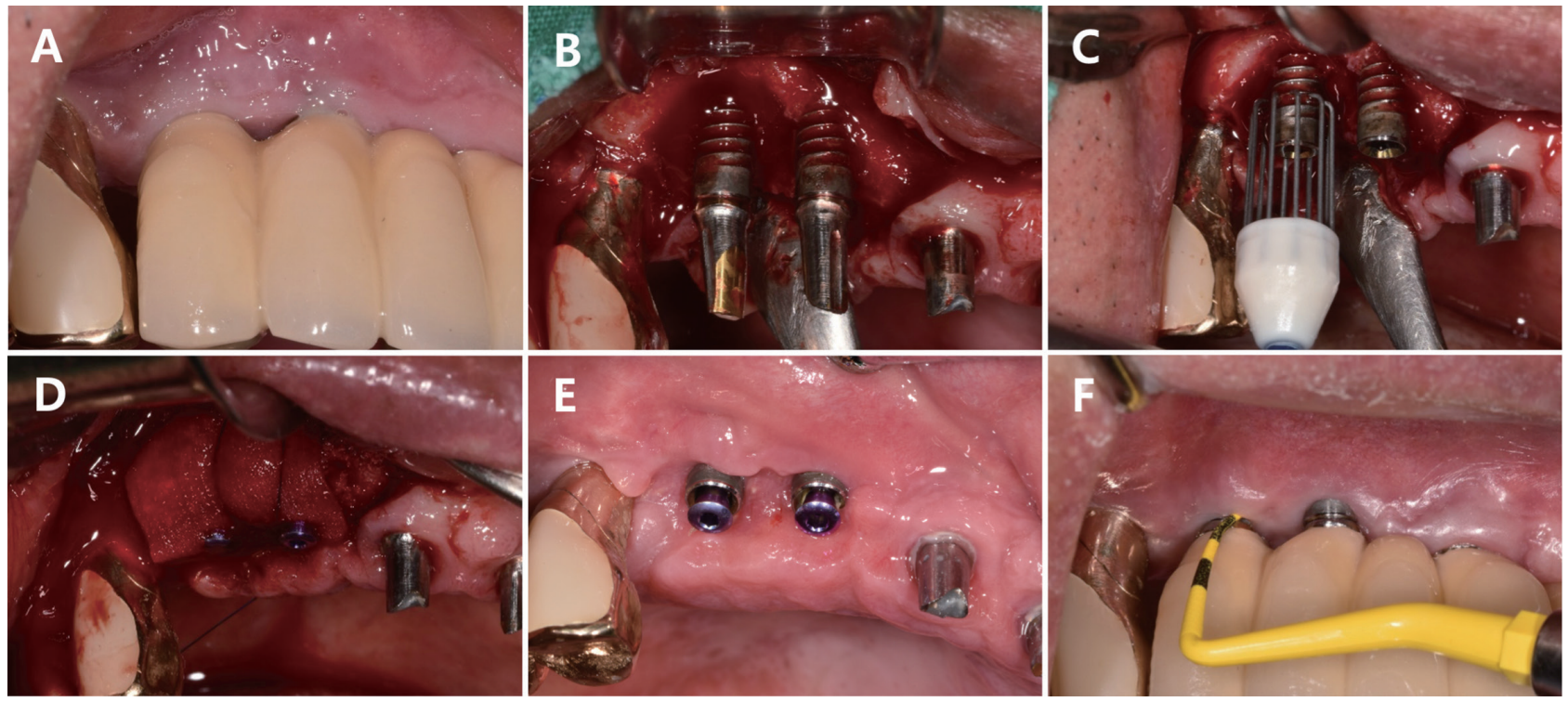

Fig. 3. Clinical photo of Case 3. (A) Preoperative photo. Note the pus discharge and gingival swelling on the right maxillary canine and $1^{\text {st }}$ premolar area, (B) Flap reflection. Note the intra-bony defect (Class Ic defect type by Schwarz et al., 2010 17 ), (C) Titanium brush application for surface decontamination, (D) Bone graft and acellular dermal matrix with cover screw, (E) Postoperative photo at 2 months. Note the exposure on the crestal area, (F) Two-year follow-up.

discomfort (Fig. 3F). The patient was kept on regular follow-up thereafter. Clinical and radiographic findings were recorded (Table 1). The $\mathrm{mPI}, \mathrm{mSBI}, \mathrm{PD}$, and DIB of 113 and i14 decreased from 0.75 to 0,1 to $0,9.3 \mathrm{~mm}$ to $3 \mathrm{~mm}$ and $9.8 \mathrm{~mm}$ to $3 \mathrm{~mm}, 6.2 \mathrm{~mm}$ to $2.8 \mathrm{~mm}$, and $9.2 \mathrm{~mm}$ to $3.4 \mathrm{~mm}$, respectively, over two years.

\section{Discussion}

A 2019 Congress Scientific Report $\left(28^{\text {th }}\right.$ European Association for Osseointegration) extensively categorizes peri-implant treatment methods into plaque control capacity, reduction of probing depth, implant surface decontamination, and bone reconstruction. ${ }^{6}$ To achieve these therapeutic goals, cleaning of the implant is important. Mechanical cleaning of an implant has limited efficacy owing to the shape of the implant screw. One study reported the lowest cleaning efficacy for the periapical sides of screw threads, followed by the areas between threads and sand thread tips. ${ }^{13}$ Among Gracey steel curettes, ultrasonic device with a steel tip, and air powder abrasives with glycine powder used to clean implants, air powder abrasives had the highest cleaning efficacy. ${ }^{13}$
Mechanical cleaning causes macroscopic and microscopic changes in the surface topography of an implant, thereby altering the surface roughness of the implant. A study examining the effect of five tools (metal scaler, Teflon tip, two types of titanium brush, and glycine air abrasive) on the surface topography of an implant reported that a metal scaler changes the macroscopic topography of an implant surface, whereas a Teflon tip leaves remnants of the plastic tip. While a metal scaler increased the surface roughness between the screw threads, the titanium brush and glycine air abrasives reduced the surface roughness between the screw threads. However, statistically significant results were observed only for titanium brushes, and they can be effectively used to clean implant valleys and reduce implant surface roughness. $^{14}$

Implantoplasty may be performed to reduce the surface roughness of an implant to improve treatment outcomes. However, the procedure can increase the risk of fracture of implants with a small diameter, ${ }^{15}$ and the titanium fragments resulting from the fracture can affect the surrounding tissues. ${ }^{16}$

The shape of a bone defect plays a crucial role on the outcome of a regenerative procedure performed 

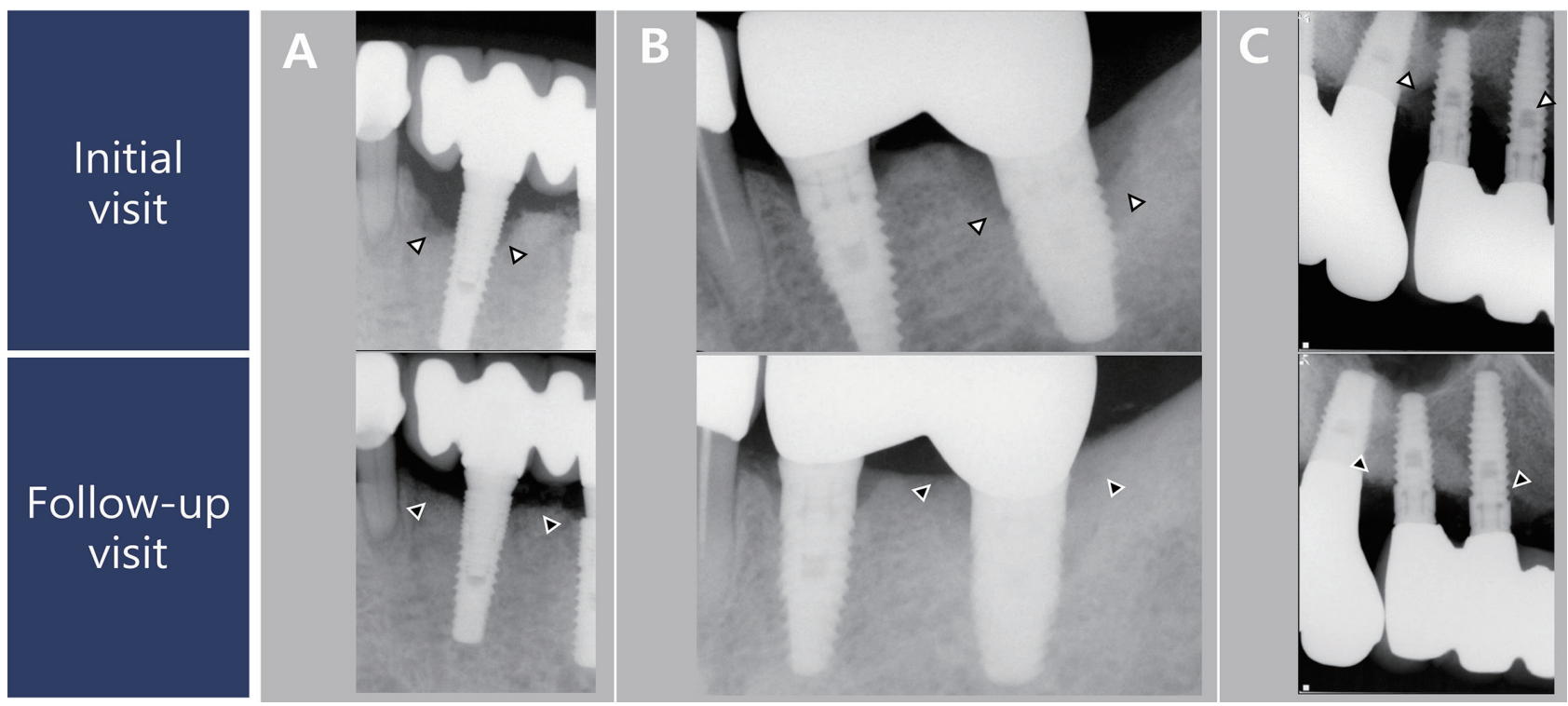

Fig. 4. Intra-oral radiographs on baseline and follow-up visits. (A) Case 1, (B) Case 2, and (C) Case 3. Black and white arrows indicate the marginal bone level on baseline and follow-up visits, respectively.

following implant surface cleaning. ${ }^{17}$ A study reported that regenerative procedures produce better outcomes for circumferential bone defects with buccal and lingual bone plates than without bone plates.

The bone defects in this case report were classified and diagnosed as supra-alveolar, circumferential, and intra-bony defects in Cases 1, 2, and 3, respectively. Although the same bone graft material was used for all three cases, different types of membrane were applied since the shapes of the bone defects varied across the cases. For Case 1, graft placement was deemed difficult since both the buccal and lingual bone plates were lost. As a result, a titanium-reinforced dense polytetrafluoroethylene membrane was placed, followed by a soft tissue graft. During the re-entry surgery, the sites of bone loss surrounding the implants in Cases 1 and 2 were observed to have healed. Since re-entry surgery for early implant exposure was not performed in Case 3, the healing progress at the site of the bone defect could not be examined in this case. The marginal bone was not restored until above the crestal module for Cases 1 and 3, unlike Case 2, based on radiographic and clinical findings (Fig. 4). Additionally, Case 3 showed buccal gingival recession and rough surface exposure
(Fig. 3, Table 1). Postoperative radiographs revealed that the bone graft did not cover the upper portion of the crestal module for Case 1, unlike in Cases 2 and 3. Case 3 failed to achieve primary wound closure, unlike in Cases 1 and 2. The depth of the implant placement and the design of the upper portion of an implant have been reported to affect marginal bone formation and resorption. ${ }^{18}$ However, the mean $\mathrm{mPI}, \mathrm{mSBI}, \mathrm{PD}$, and DIB of the three cases decreased from 1.12 to $0.19,1.38$ to $0.25,8.73 \mathrm{~mm}$ to $3 \mathrm{~mm}$, and 6.35 to $2.3 \mathrm{~mm}$, respectively, over the relatively short follow-up period of two years. The bone fill of approximately $4 \mathrm{~mm}$ in this case was comparable to the $1.9-4.2 \mathrm{~mm}$ bone fill observed in previous studies ${ }^{7}$ on GBR. The reduction of probing depth in these cases was good compared to that obtained in other studies using a rotary titanium brush. ${ }^{11}$ Improvements in symptoms, such as an absence of discomfort, were also reported.

All three patients required long-term follow-up. The use of a titanium brush may improve the prognosis of a regenerative procedure as it cleans the implant surface and maintains the implant surface roughness and shape of screw threads. However, the risk of implant fragment generation during tool ma- 
nipulation should be considered. A titanium brush should be used with caution and sufficient irrigation to reduce the risk of implant fragment generation. ${ }^{19}$ However, following the regenerative procedure in which an implant surface was decontaminated using a rotary titanium brush and the site of bone defect was restored using a bone graft, all implants were well maintained with stable clinical and periapical radiographic findings throughout the two-year followup period.

\section{Conclusion}

A surgical approach using GBR and bone graft can effectively treat peri-implantitis accompanied by bone loss. A titanium brush can be used for mechanical cleaning of the implant surface, which can be helpful for regenerative treatment of peri-implantitis. Research with a longer follow-up period is warranted to support the findings of this study.

\section{Acknowledgements}

This study was supported by a Veterans Health Service Medical Center Research Grant, Republic of Korea (Grant number: VHSMC 21049).

\section{ORCID}

Min-Woo Baek https://orcid.org/0000-0001-6851-2836 Jeoung-A Yu https://orcid.org/0000-0001-8808-5691 Seong-Ho Choi https://orcid.org/0000-0001-6704-6124 Dong-Woon Lee https://orcid.org/0000-0002-0796-9100

\section{References}

1. Lang NP, Berglundh T, Working Group 4 of Seventh European Workshop on Periodontology. Periimplant diseases: where are we now? - Consensus of the Seventh European Workshop on Periodontology. J Clin Periodontol 2011;38 Suppl 11:178-81.

2. Derks J, Tomasi C. Peri-implant health and disease. A systematic review of current epidemiology. J Clin Periodontol 2015;42 Suppl 16:S158-71.

3. Elemek E, Agrali OB, Kuru B, Kuru L. Peri-im- plantitis and Severity Level. Eur J Dent 2020;14:2430.

4. Alani A, Bishop K. Peri-implantitis. Part 3: current modes of management. Br Dent J 2014;217:345-9.

5. Kotsailidi EA, Michelogiannakis D, Al-Zawawi AS, Javed F. Surgical or non-surgical treatment of peri-implantitis - what is the verdict? Surg Prac Sci 2020;1:100010.

6. Sanchez IS. Congress Scientific Report 2019 EAO 28th Annual Scientific Meeting. Available from: https://csr2019.eao.org/home/dealing-with-complications/how-to-treat-peri-implantitis (updated 2021 Dec 17).

7. Renvert S, Polyzois I, Claffey N. Surgical therapy for the control of peri-implantitis. Clin Oral Implants Res 2012;23:84-94.

8. Roos-Jansaker AM, Persson GR, Lindahl C, Renvert S. Surgical treatment of peri-implantitis using a bone substitute with or without a resorbable membrane: a 5-year follow-up. J Clin Periodontol 2014; 41:1108-14.

9. Bassi F, Poli PP, Rancitelli D, Signorino F, Maiorana C. Surgical Treatment of Peri-Implantitis: A 17Year Follow-Up Clinical Case Report. Case Rep Dent 2015;2015:574676.

10. Schwarz F, Herten M, Sager M, Bieling K, Sculean A, Becker J. Comparison of naturally occurring and ligature-induced peri-implantitis bone defects in humans and dogs. Clin Oral Implants Res 2007;18: 161-70.

11. An YZ, Lee JH, Heo YK, Lee JS, Jung UW, Choi SH. Surgical treatment of severe peri-implantitis using a round titanium brush for implant surface decontamination: a case report with clinical reentry. J Oral Implantol 2017;43:218-25.

12. Buser D, Chappuis V, Kuchler U, Bornstein MM, Wittneben JG, Buser R, Cavusoglu Y, Belser UC. Long-term stability of early implant placement with contour augmentation. J Dent Res 2013;92:176S82S.

13. Steiger-Ronay V, Merlini A, Wiedemeier DB, Schmidlin PR, Attin T, Sahrmann P. Location of unaccessible implant surface areas during debridement in simulated peri-implantitis therapy. BMC Oral Health 2017;17:137. 
14. Cha JK, Paeng K, Jung UW, Choi SH, Sanz M, Sanz-Martin I. The effect of five mechanical instrumentation protocols on implant surface topography and roughness: A scanning electron microscope and confocal laser scanning microscope analysis. Clin Oral Implants Res 2019;30:578-87.

15. Costa-Berenguer X, Garcia-Garcia M, SanchezTorres A, Sanz-Alonso M, Figueiredo R, Valmaseda-Castellon E. Effect of implantoplasty on fracture resistance and surface roughness of standard diameter dental implants. Clin Oral Implants Res 2018;29:46-54.

16. Stavropoulos A, Bertl K, Eren S, Gotfredsen K. Mechanical and biological complications after implantoplasty-A systematic review. Clin Oral Implants Res 2019;30:833-48.

17. Schwarz F, Sahm N, Schwarz K, Becker J. Impact of defect configuration on the clinical outcome following surgical regenerative therapy of periimplantitis. J Clin Periodontol 2010;37:449-55.

18. Saleh MHA, Ravidà A, Suárez-López del Amo F, Lin GH, Asa'ad F, Wang HL. The effect of implant-abutment junction position on crestal bone loss: A systematic review and meta-analysis. Clin Implant Dent Relat Res 2018;20:617-33.

19. Valderrama P, Wilson TG Jr. Detoxification of implant surfaces affected by peri-implant disease: an overview of surgical methods. Int J Dent 2013; 2013:740680. 


\section{회전형 타이타늄 브러쉬를 이용한 임플란트 주위염 재생술식: 2년 추적결과 증례 보고}

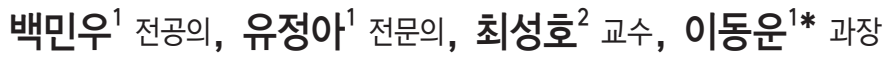

${ }^{1}$ 중앙보훈병원 치과병원 치주과

${ }^{2}$ 연세대학교 치과대학 치주과학교실, 치주조직재생연구소

본 증례보고에서는 임플란트 주위염으로 진단된 임플란트의 오염된 표면을 회전형 타이타늄 브러쉬로 처리후 재생적 처 치를 시도한 3가지 증례에 대한 임상적 및 방사선학적 평가를 목적으로 하였다. 2 년간 추적결과에서 3 가지 증례의 평균 변형치태지수가 1.12 에서 0.19 로, 변형열구출혈지수가 1.38 에서 0.25 로, 치주낭 깊이가 $8.73 \mathrm{~mm}$ 에서 $3 \mathrm{~mm}$ 로, 임플란트 상부와 골이 처음 접하는 부위까지의 거리값이 $6.35 \mathrm{~mm}$ 에서 $2.3 \mathrm{~mm}$ 로 감소하는 개선을 보였으며, 기존의 보철물로 유 지할 수 있었다. 향후 장기적인 추적을 통해 본 술식의 효과를 뒷받침할 수 있는 근거를 마련할 것이 필요할 것이다.

(구강회복응용과학지 2021;37(4):259-67)

주요어: 치과 임플란트; 임플란트 주위염; 골재생

*교신저자: 이동운

(05368) 서울특별시 강동구 진황도로61길 53 중앙보훈병원 치과병원 치주과

Tel: 02-2225-1928 | Fax: 02-2225-1659 | E-mail: dongden@daum.net

접수일: 2021년 8월 30일 | 수정일: 2021년 10월 7일 | 채택일: 2021년 10월 18일 